\title{
First chromosomal analysis of Gymnorhamphichthys britskii: the remarkable lowest diploid value within the family Rhamphichthyidae (Gymnotiformes)
}

\author{
Carlos Alexandre Fernandes ${ }^{1}$, Allan Kardec Moreira de Aguiar ${ }^{1}$, Leonardo Marcel Paiz ${ }^{2}$, \\ Lucas Baumgärtner ${ }^{2}$, Diovani Piscor ${ }^{1}$ and Vladimir Pavan Margarido ${ }^{2,3}$
}

Gymnorhamphichthys britskii is a Neotropical electric fish of family Rhamphichthyidae described from the Paraná-Paraguay system. This study reports the first karyotypic description of G. britskii collected from the upper Paraná river basin, which presented $2 \mathrm{n}=38$ chromosomes, karyotype composed of 14 metacentric, 8 submetacentric, 2 subtelocentric and 14 acrocentric chromosomes, and fundamental number as 62 for both sexes. Heteromorphic sex chromosomes were absent. A single pair of nucleolar organizing regions (NORs) was detected in the submetacentric chromosome pair number 9 by silver staining and confirmed by the 18S rDNA probe. The $5 \mathrm{~S}$ rDNA was located in a single chromosome pair. Heterochromatic regions were clearly observed in the short arms of the NOR-bearing chromosome pair and in the telomeric positions of most acrocentric chromosomes. Besides the present data are valuable to help in understanding karyotypic evolution in Rhamphichthyidae, data from NORs confirmed the tendency of this family in presenting simple NORs sites, similar to the other Gymnotiformes clades. Yet, the presence of a large heterochromatic block in the NOR-bearing chromosome can be used as cytogenetic markers for G. britskii, and that centric fusions appear to be an important mechanism in the karyotype evolution and differentiation among Gymnotiformes species.

Keywords: Ag-NORs, C-banding, Fish cytogenetics, Karyotype evolution, Repetitive sequences.

Gymnorhamphichthys britskii é um peixe neotropical da família Rhamphichthyidae descrita no sistema Paraná-Paraguai. Este estudo relata a primeira descrição cariotípica de G. britskii coletado na bacia do alto rio Paraná, que apresentou $2 \mathrm{n}=$ 38 cromossomos, cariótipo composto por 14 metacêntricos, 8 submetacêntricos, 2 subtelocêntricos e 14 acrocêntricos, e número fundamental 62 para ambos sexos. Cromossomos sexuais heteromórficos estavam ausentes. Um único par de regiões organizadoras de nucléolos (RONs) foi detectado no par de cromossomos submetacêntricos número 9 por coloração com prata e confirmado pela sonda DNAr 18S. O DNAr $5 \mathrm{~S}$ foi localizado em um único par cromossômico. Regiões heterocromáticas foram claramente observadas nos braços curtos do par de cromossomos que carrega a RON e nas posições teloméricas da maioria dos cromossomos acrocêntricos. Além dos dados presentes serem valiosos para auxiliar na compreensão da evolução cariotípica em Rhamphichthyidae, dados de RONs confirmaram a tendência desta família em apresentar sítios simples de RONs, semelhantes aos demais clados de Gymnotiformes. No entanto, a presença de um grande bloco heterocromático no cromossomo portador da RON, pode ser usado como marcador citogenético para G. britskii e as fusões cêntricas parecem ser um mecanismo importante na evolução e diferenciação cariotípica entre as espécies de Gymnotiformes.

Palavras-chave: Ag-RONs, Bandeamento C, Citogenética de peixes, Evolução cariotípica, Sequências repetitivas.

\section{Introduction}

The Gymnorhamphichthys Ellis, 1912 is a representant of the clade Rhamphichthyidae, a group of Neotropical electric fishes, widely distributed through the cis-Andean drainages of tropical South America, from Venezuela to northeast Argentina (Nijssen et al., 1976). The genus is composed of five valid species: G. rondoni (Miranda Ribeiro, 1920), G. rosamariae Schwassmann, 1989, G. bogardusae Lundberg, 2005, G. hypostomus Ellis, 1912, and G. britskii Carvalho, Ramos \& Albert, 2011 (Fricke et al., 2019).

\footnotetext{
${ }^{1}$ Universidade Estadual de Mato Grosso do Sul, Unidade Universitária de Mundo Novo, Rodovia BR 163-Km 20.2, 79980-000 Mundo Novo, MS, Brazil. (CAF) fxande@gmail.com, ○https://orcid.org/0000-0002-9905-1507 (corresponding author); (AKMA) allankardecmoreiradeaguiar@ gmail.com, Dhttps://orcid.org/0000-0001-8769-1198; (DP) diovanipis@gmail.com, @https://orcid.org/0000-0002-2375-5997

${ }^{2}$ Centro de Ciências Biológicas e da Saúde, Universidade Estadual do Oeste do Paraná, Cascavel, Paraná, Brazil. (LMP) leonardo_paiz@, hotmail.com, Ohttps://orcid.org/0000-0002-4761-8321; (LB) baumgartner.lb@gmail.com, Dhttps://orcid.org/0000-0002-6633-3006

${ }^{3}$ Centro de Ciências Biológicas, Universidade Estadual de Maringá, Maringá, Paraná, Brazil. (VPM) vladimir.margarido@unioeste.br, Dhttps://orcid.org/0000-0002-0823-6646
} 
Gymnorhamphichthys britskii is distributed from tributaries of the La Plata River system, and share with G. hypostomus a distinct color pattern of the dorsum composed of a few large, dark saddles, which is not present in any other species of Rhamphichthyidae (Carvalho et al., 2011). Previously, there were no records of G. britskii from the upper Paraná River before the construction of the Itaipu Dam. The distribution of G. britskii (referred to as Gymnorhamphichthys sp. by Graça, Pavanelli, 2007) in the upper Paraná River seems to be due to the construction of Itaipu Dam, which by elevating a portion of the lower Paraná River effectively eliminated the Sete Quedas falls as a barrier for dispersal (Langeani et al., 2007; Ota et al., 2018).

The families Hypopomidae and Rhamphichthyidae are closely related and constitute the superfamily Rhamphichthyoidea (Albert, 2001). No cytogenetic information is available for species of Gymnorhamphichthys. Among the other Rhamphichthyidae, cytogenetic information is available only for Hypopygus lepturus Hoedeman, 1962 (AlmeidaToledo, 1978), Steatogenys duidae (La Monte, 1929), S. elegans (Steindachner, 1880) (Cardoso et al., 2011), Rhamphichthys hahni (Meinken, 1937), R. pantherinus Castelnau, 1855 (cited as $R$. marmoratus) and $R$. rostratus (Linnaeus, 1766) (Mendes et al., 2012; Silva et al., 2013). Among the Hypopomidae, it is available for Hypopomus artedi (Kaup, 1856) (Almeida-Toledo, 1978), eight Brychyhypopomus species (Almeida-Toledo, 1978; Mendes et al., 2012; Cardoso et al., 2018) and Microsternarchus bilineatus Fernández-Yépez, 1968 (de Jesus et al., 2016; Batista et al., 2017).

There are still few cytogenetic studies regarding Rhamphichthyoidea, but they show that these species present great differences in relation to the number of chromosomes and karyotype macrostructure. In Rhamphichthyidae all species had $2 \mathrm{n}=50$ chromosomes but differed in their karyotypes (Almeida-Toledo, 1978; Cardoso et al., 2011; Mendes et al., 2012; Silva et al., 2013). Among the Hypopomidae, the diploid number ranged from 36 (Brachyhypopomus brevirostris (Steindachner, 1868)) to 48 (M. bilineatus) chromosomes (de Jesus et al., 2016; Batista et al., 2017; Cardoso et al., 2018).

The physical mapping of ribosomal DNAs, especially $5 \mathrm{~S}$ and $18 \mathrm{~S}$ rDNAs, has been frequently used by cytogenetic studies on Neotropical fish, including fishes of the order Gymnotiformes (Fernandes et al., 2017a,b) to assist the clarification of taxonomic, biogeographical and phylogenetic problems. In Rhamphichthyidae, cytogenetic studies about the distribution of ribosomal genes (18S rDNA) are restricted to karyotypes of $S$. duidae, S. elegans (Cardoso et al., 2011), R. hahni, R. pantherinus and $R$. rostratus (Mendes et al., 2012; Silva et al., 2013), demonstrating only one chromosome pair bearing these clusters in all species.
No cytogenetic information is available for physical mapping of 5S rDNA in the Rhamphichthyidae. Therefore, in an effort to collect more information about chromosomal diversity within the family Rhamphichthyidae, this study establishes the first cytogenetic description of G. britskii by classic and molecular cytogenetics techniques.

\section{Material and Methods}

Twenty-two ( 8 males, 9 females and 5 sex indeterminate) individuals of $G$. britskii from Dourado stream, Mato Grosso

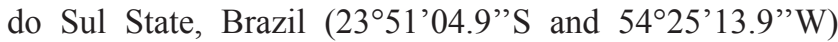
were analysed. This stream is a tributary of the right margin of the Iguatemi River, which belongs to the upper Paraná River basin (Fig. 1).

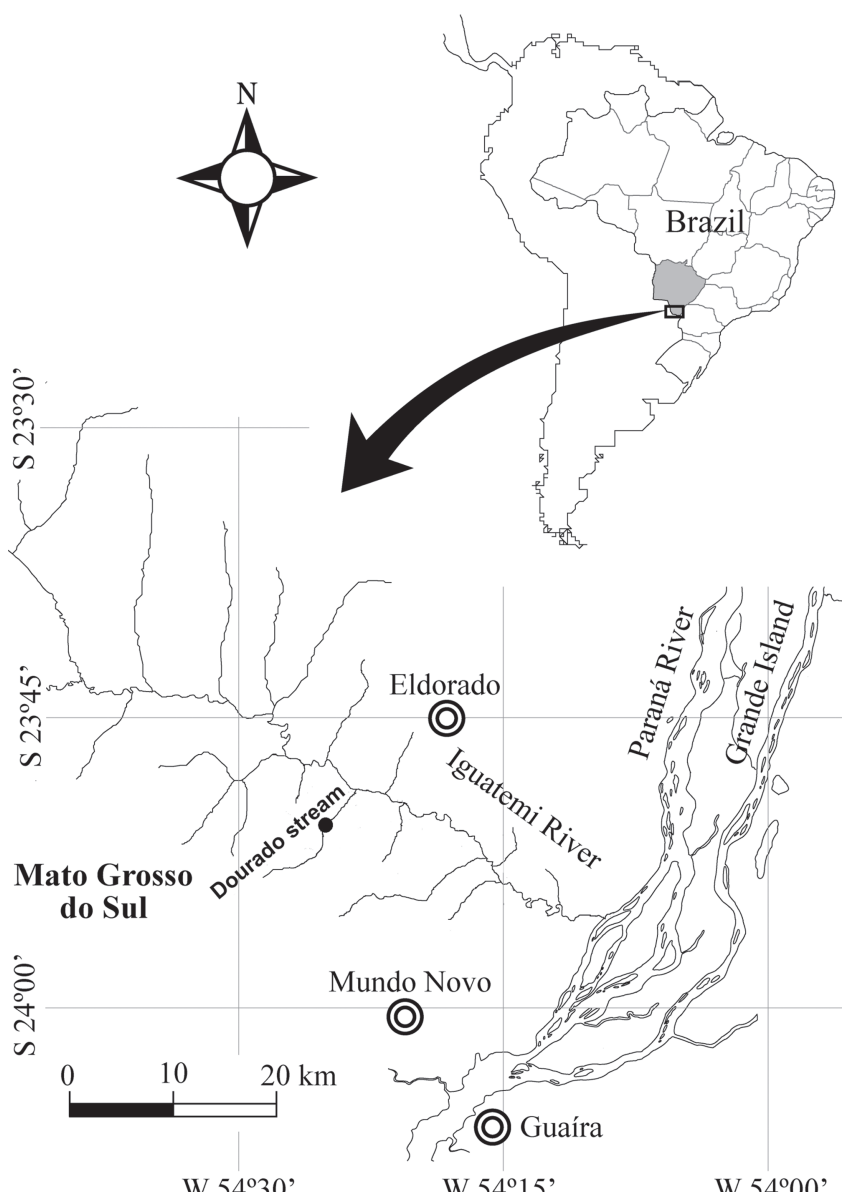

Fig. 1. Location of Dourado stream in the upper Paraná River basin where Gymnorhamphichthys britskii individuals were captured. The dark circle indicates the sampling spots.

Animals were captured with the permission of the Instituto Chico Mendes de Conservação da Biodiversidade (ICMBio; number 64611). Voucher specimens were deposited in the fish collection of the Núcleo de Pesquisas em Limnologia, Ictiologia e Aquicultura (NUPELIA), Universidade Estadual de Maringá, PR Brazil, as Gymnorhamphichthys britskii (NUP 16251) (Fig. 2). 


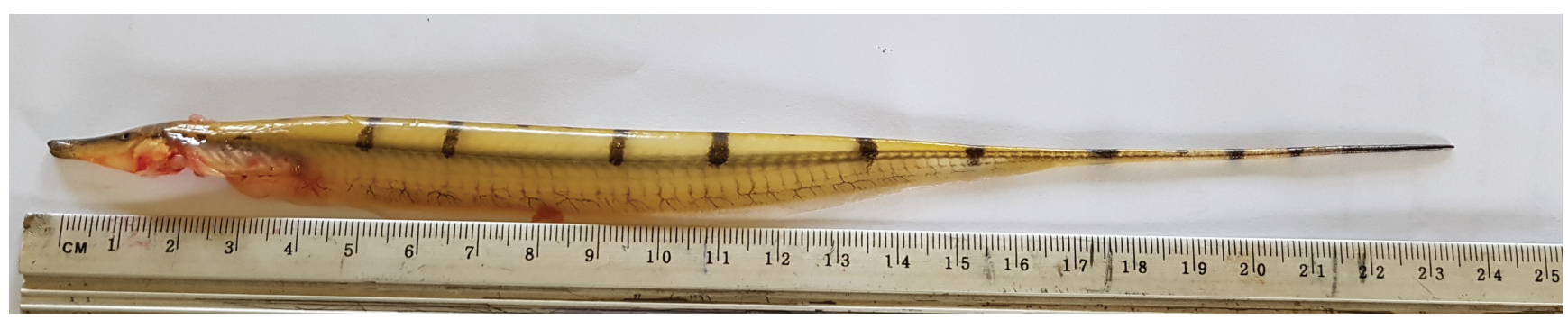

Fig. 2. Gymnorhamphichthys britskii sampled in the Dourado stream, Mato Grosso do Sul State, Brazil.

This study was carried out in strict accordance with the recommendations of the Guide for the Care and Use of Laboratory Animals, approved by the Committee on Ethics of Animal Experiments of the Universidade Estadual do Mato Grosso do Sul (License Number: Protocol 024/2018 - CEUA/UEMS). The experiments followed the ethical conduct, and before euthanasia, the fish were anesthetized by an overdose of clove oil (Griffiths, 2000). Metaphase chromosomes were obtained from anterior kidney cells using the air-drying technique (Bertollo et al., 1978). C-positive heterochromatin (C-bands) was visualized by the procedure of Sumner (1972), with minor adaptations. NORs were detected by means of silver nitrate staining (Ag-NORs), according to Howell, Black (1980).

At least 30 metaphases were analyzed for each individual and those with better chromosome morphology were used for the karyotype analysis. The chromosomes are classified as metacentric $(\mathrm{m})$, submetacentric $(\mathrm{sm})$, subtelocentric (st), and acrocentric (a) according to Levan et al. (1964). The fundamental number (FN) is calculated according to the chromosomal arm numbers (the chromosomes $\mathrm{m}$, sm and st are considered to contain two arms $-p$ and $q$ arms - and the a with one arm —only $q$ arm).

Physical mapping of the $5 \mathrm{~S}$ and $18 \mathrm{~S}$ rDNA was carried out by fluorescence in situ hybridization (FISH) according to Pinkel et al. (1986) and modifications suggested by Margarido, Moreira-Filho (2008), using DNA probes obtained from the genomes of Megaleporinus elongatus (Valenciennes, 1850) (Martins, Galetti, 1999) and Prochilodus argenteus Spix \& Agassiz, 1829 (Hatanaka, Galetti, 2004), respectively. The probes were labelled through nick translation, with digoxigenin-11-dUTP (18S rDNA) and biotin-16-dUTP (5S rDNA) (Roche). Detection and amplification of the hybridization signal were carried out using avidin-FITC and anti-avidin biotin (Sigma) for probes labelled with biotin, and antidigoxigenin rhodamine (Roche) for probes labelled with digoxigenin. Slides were counterstained with DAPI (4'6-Diamine-2'-phenylindole dihydrochloride) (50

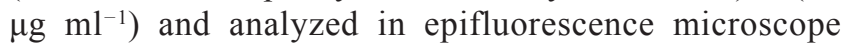
(Olympus BX61). The images were captured using the software DP controller (Media Cybernetics) and the image composition was carried out with Adobe Photoshop CS6.

\section{Results}

All the twenty-two individuals of $G$. britskii had $2 \mathrm{n}=38$ chromosomes and karyotype composed of $14 \mathrm{~m}, 8 \mathrm{sm}, 2 \mathrm{st}$ and $14 \mathrm{a}$, and $\mathrm{FN}=62$ for both sexes (Fig 3a). Heteromorphic sex chromosomes were absent. A secondary constriction was observed in the terminal region of the $p$ arm of the sm pair number 9, which corresponds to the Ag-NORs signals (Fig. 3a, in box) and also had a clear size heteromorphism (Figs. 3a, c).

The heterochromatins were preferentially located in the centromeric and pericentromeric regions in various chromosomes. Large terminal blocks were evidenced on the $q$ arm of the pairs number 13, 15, 16 (one homolog) and 17, and a large heterochromatic block on the $p$ arm of the pair number 9 flanked by NOR (Fig. 3b).

Double FISH with $18 \mathrm{~S}$ and 5S rDNA probes confirmed the Ag-NORs sites and did not detect any further inactive major ribosomal clusters (Fig. 3c); in addition, it showed that minor rDNA clusters occur interstitially in the acrocentric pair number 13 and do not co-localize with the major rDNA clusters (Fig. 3c).

\section{Discussion}

The lack of karyotype data for several fish groups impairs comparative analyzes on their evolutionary trends and chromosomal relationships. This is the case for the family Rhamphichthyidae for which chromosomal characteristics are known only for three genera: Rhamphichthys, Hypopygus and Steatogenys, and all species presented 50 chromosomes. In this sense, this study is the first one providing classical and molecular cytogenetic data for one of its representative species, G. britskii.

Both male and female specimens of $G$. britskii have the same karyotype structure, with $2 \mathrm{n}=38$ chromosomes $(14 \mathrm{~m}$ $+8 \mathrm{sm}+2 \mathrm{st}+14 \mathrm{a})$, with no evidence of differentiated sex chromosomes. Diploid number of 38 chromosomes found in G. britskii differs from the findings for every other species of the same family. Compared to other rhamphichthyids that have $2 \mathrm{n}=50$, the karyotype of $G$. britskii suggested a reduction in the $2 \mathrm{n}$, indicating that chromosome rearrangements, such as centric fusions that can alter the chromosome number may have occurred during the diversification of this group. 

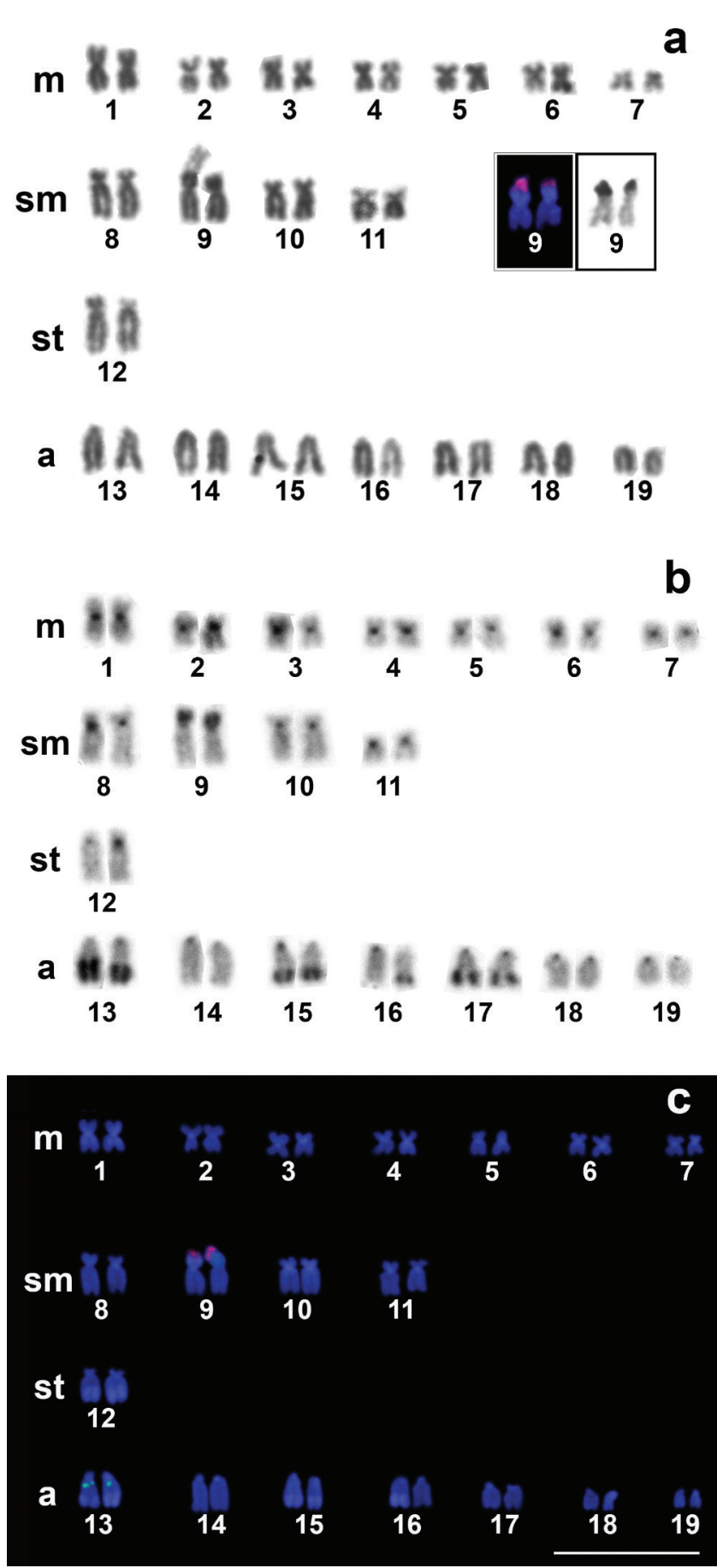

Fig. 3. Karyotypes of Gymnorhamphichthys britskii arranged a. from Giemsa stained; b. C-banded; and c. after doubleFISH with $18 \mathrm{~S}$ rDNA (red) and 5S rDNA (green) probes.. The NOR-bearing chromosomes (pair 9) are in the box. Note the size heteromorphism involving the NORs detected by the AgNOR and 18S rDNA-FISH techniques. Scales bar $=10 \mu \mathrm{m}$.

Chromosome fusions were identified as important events in the diversification of Hypopomidae (the sister group of Rhamphichthyidae), in which the diploid number varies between 36 chromosomes, as in B. brevirostris, and 48 chromosomes, as in M. bilineatus (de Jesus et al., 2016; Batista et al., 2017; Cardoso et al., 2018). In Rhamphichthyidae, the chromosomic data of $G$. britskii alter the paradigm of karyotype evolution characterized by $2 \mathrm{n}$ conservation (50 chromosomes) and chromosome inversions (Cardoso et al., 2011; Mendes et al., 2012; Silva et al., 2013). Nonetheless, more rhamphichthyid species need to be cytogenetically analyzed to confirm this hypothesis (diversification by chromosome fusions). Moreover, centric fusion is the mechanism proposed in the origin of multiple sex chromosome system found in Gymnotiformes species belonging each one to different families: Eigenmannia sp. 2 (Almeida-Toledo et al., 2000a), E. trilineata (Fernandes et al., 2010), Brachyhypopomus gauderio (Mendes et al., 2012), B. pinnicaudatus (Almeida-Toledo et al., 2000b), Gymnotus pantanal (cited as Gymnotus sp., Silva, Margarido, 2005), G. coropinae (da Silva et al., 2014). According to Silva, Margarido (2005), the presence of a same $\mathrm{X}_{1} \mathrm{X}_{1} \mathrm{X}_{2} \mathrm{X}_{2} / \mathrm{X}_{1} \mathrm{X}_{2} \mathrm{Y}$ sex chromosome system in six species seems to be a homoplasic event, and it is highly probable that this apomorphic character has arisen by independent events. Thus, centric fusions appear to be an important and common mechanism acting in the karyotype evolution and differentiation among Gymnotiformes species.

NORs were located in terminal position on the $p$ arm number 9, as revealed by the Ag-NOR and $18 \mathrm{~S}$ rDNAFISH techniques (Fig. 3a, box), thus characterizing a simple NORs system in G. britskii. Similar pattern was observed in karyotypes of $S$. duidae, S. elegans (Cardoso et al., 2011), $R$. hahni, $R$. pantherinus and $R$. rostratus (Mendes et al., 2012; Silva et al., 2013). A single chromosome pair with NORs sites is thought to be a plesiomorphic characteristic of the Rhamphichthyidae. By contrast, multiple NORs sites have characterized the karyotypes of the Hypopomidae.

In $G$. britskii, size heteromorphism involving the NORs was detected by the Ag-NOR and 18S rDNA-FISH techniques. This characteristic can be explained mainly by unequal recombination or random duplication (Gornung, 2013). Events as these can be observed in chromosomes regions composed of repetitive DNA. In G. britskii, the NORs are flanked by heterochromatin. Heterochromatic regions and ribosomal genes are known to contain highly repetitive DNA. Therefore, our results reinforce the suggestion of Fernandes-Matioli et al. (1998) that heterochromatic regions bordering NORs tend to favor chromosome rearrangements in these particular chromosome areas.

The present study performed the first physical mapping of the 5S DNA in chromosomes of Rhamphichthyidae. In $G$. britskii, the 5S rDNA is located in a single chromosome pair and nonsyntenic with the $18 \mathrm{~S}$ rDNA sites, a common characteristic of several fish groups (Pisano et al., 2007). Simple 5S rDNA sites were also observed in karyotypes of $M$. bilineatus, but in only one chromosome of the $12^{\text {th }}$ pair in males showed synteny between the $18 \mathrm{~S}$ rDNA and 5S rDNA sites (de Jesus et al., 2016). Moreover, in M. bilineatus the 5S rDNA cistrons are located in the terminal region, while in $G$. britskii these cistrons are located in the interstitial position. 
The heterochromatin distribution follows the general pattern usually found in many other fish species, preferentially centromeric localization. In contrast, large telomeric heterochromatic blocks in acrocentric chromosomes were verified in G. britskii, but not observed in Rhamphichthys and Steatogenys (Cardoso et al., 2011; Mendes et al., 2012; Silva et al., 2013). Moreover, G. britskii had a conspicuous large heterochromatic block in the NOR-bearing chromosomes, adjacent to secondary constriction that can be used as cytogenetic markers for the species.

The results presented in this study allowed the first cytogenetic characterization of a species within the Gymnorhamphichthys genus, contributing to the karyotype knowledge of the family Rhamphichthyidae. Data from NORs confirmed the tendency of this family in presenting simple NORs sites, similar to the other Gymnotiformes clades. We also reported the presence of a large heterochromatic block in the NOR-bearing chromosome, adjacent to secondary constriction, which can be used as cytogenetic markers for G. britskii, and that centric fusions appear to be an important mechanism in the karyotype evolution and differentiation among Gymnotiformes species.

\section{Acknowledgments}

The authors thank Dr. Weferson Júnio da Graça for the taxonomic identification of the specimens. Besides, we are grateful to the Ministério do Meio Ambiente/ Instituto Chico Mendes de Conservação da Biodiversidade (MMA/ ICMBio - License number 64611) for authorizing the collection of the biological material.

\section{References}

Albert JS. Species diversity and phylogenetic systematics of American knifefishes (Gymnotiformes, Teleostei). Misc Publi Mus Zoo. 2001; 190:1-127

Almeida-Toledo LF. Contribuição a citogenética dos Gymnotoidae (Pisces, Ostariophysi). Ph.D. Thesis, Instituto de Biociências da Universidade de São Paulo, São Paulo; 1978.

Almeida-Toledo LF, Foresti F, Daniel MFZ, Toledo-Filho SA. Sex chromosome evolution in fish: the formation of the neo-Y chromosome in Eigenmannia (Gymnotiformes). Chromosoma. 2000a; 109(3):197-200. https://doi.org/10.1007/ s004120050428

Almeida-Toledo LF, Daniel-Silva MFZ, Lopes CE, Toledo-Filho SA. Sex chromosome evolution in fish. II. Second occurrence of an $\mathrm{X}_{1} \mathrm{X}_{2} \mathrm{Y}$ sex chromosome system in Gymnotiformes. Chromosome Res. 2000b; 8(4):335-40. https://doi. org/10.1023/A:1009287630301

Batista JA, Cardoso AL, Milhomem-Paixão SSR, Ready JS, Pieczarka JC, Nagamachi CY. The karyotype of Microsternarchus aff. bilineatus: a first case of Y chromosome degeneration in Gymnotiformes. Zebrafish. 2017; 14(3):24450. https://doi.org/10.1089/zeb.2016.1383
Bertollo LAC, Takahashi CS, Moreira-filho O. Cytotaxonomic considerations on Hoplias lacerdae (Pisces, Erythrinidade). Braz J Genet. 1978; 1(1):103-20.

Cardoso AL, Pieczarka JC, Crampton WGR, Ready JS, Figueiredo Ready WMB, Waddell JC, Oliveira JA, Nagamachi CY. Karyotypic diversity and evolution in a sympatric assemblage of neotropical electric knifefish. Front Genet. 2018; 9:81. https://doi.org/10.3389/fgene.2018.00081

Cardoso AL, Pieczarka JC, Feldberg E, Milhomem SSR, Moreira-Almeida T, Silva DS, Da Silva PC, Nagamachi CY. Chromosomal characterization of two species of genus Steatogenys (Gymnotiformes: Rhamphichthyoidea: Steatogenini) from the Amazon basin: sex chromosomes and correlations with Gymnotiformes phylogeny. Rev Fish Biol Fish. 2011; 21(3):613-21. https://doi.org/10.1007/s11160-0109196-0

Carvalho TP, Ramos CS, Albert JS. A new species of Gymnorhamphichthys (Gymnotiformes: Rhamphichthyidae) from the Paraná-Paraguay basin. Copeia. 2011; 3:400-06. https://doi.org/10.1643/CI-10-154

Fernandes CA, Bailly D, Silva VFB, Martins-Santos IC. System of multiple sex chromosomes in Eigenmannia trilineata López \& Castello, 1966 (Sternopygidae, Gymnotiformes) from Iguatemi River Basin, MS, Brazil. Cytologia. 2010; 75(4):463-66. https://doi.org/10.1508/cytologia.75.463

Fernandes CA, Paiz LM, Baumgärtner L, Margarido VP, Vieira MMR. Comparative cytogenetics of the black ghost knifefish (Gymnotiformes: Apteronotidae): Evidence of chromosomal fusion and pericentric inversions in karyotypes of two Apteronotus species. Zebrafish. 2017a; 14(5):471-76. https:// doi.org/ 10.1089/zeb.2017.1432

Fernandes CA, Baumgartner L, Paiz LM, Margarido VP, Portela-Castro ALB. Chromosomal characteristics of rDNA in a conserved karyotype of two Sternopygus macrurus (Gymnotiformes: Sternopygidae) populations from upper Paraná River basin. Biologia. 2017b; 72(6):680-85. https://doi. org/10.1515/biolog-2017-0071

Fernandes-Matioli FMC, Marchetto MCN, Almeida-Toledo LA, Toledo-Filho AS. High intraspecific karyological conservation in four species of Gymnotus (Pisces: Gymnotiformes) from Southeastern Brazilian basins. Caryologia. 1998; 51(3-4):22134. https://doi.org/10.1080/00087114.1998.10797414

Fricke R, Eschmeyer WN, Van Der Laan R, editors. Catalog of Fishes: Genera, Species, References [Internet]. California Academy of Sciences; 2018 [updated June, 01, 2019; cited in June, 20, 2019]. http://researcharchive.calacademy.org/ research/ichthyology/catalog/fishcatmain.asp.

Gornung E. 2013: Twenty years of physical mapping of major ribosomal RNA genes across the teleosts: A review of research. Cytogenet Genome Res. 2013; 141(2-3):90-102. https://doi. org/10.1159/000354832

Graça WJ, Pavanelli CS. Peixes da planície de inundação do alto rio Paraná e áreas adjacentes. Maringá: Eduem; 2007.

Griffiths S. The use of clove oil as an anaesthetic and method for sampling intertidal rockpool fishes. J Fish Biol. 2000; 57(6):145364. https://doi.org/10.1111/j.1095-8649.2000.tb02224.x 
Hatanaka T, Galetti Jr PM. Mapping of the 18S and 5S ribosomal RNA genes in the fish Prochilodus argenteus Agassiz, 1829 (Characiformes, Prochilodontidae). Genetica. 2004; 122(3):239-44. https://doi.org/10.1007/s10709-004-2039-y

Howell WM, Black DA. Controlled silver-staining of nucleolus organizer regions with a protective coloidal developer: a 1-step method. Experientia. 1980; 36(8):1014-15. https://doi. org/10.1007/BF01953855

de Jesus IS, Ferreira M, Garcia C, Ribeiro LB, Alves-Gomes JA, Feldberg E. First cytogenetic description of Microsternarchus bilineatus (Gymnotiformes: Hypopomidae) from Negro river (Brazilian Amazon). Zebrafish. 2016; 13(6):571-77. https:// doi.org/10.1089/zeb.2016.1281

Langeani F, Castro RMC, Oyakawa OT, Shibatta OA, Pavanelli CS, Casatti L. Diversidade da ictiofauna do alto rio Paraná: composição atual e perspectivas futuras. Biota Neotrop. 2007; 7(3):1-17. http://dx.doi.org/10.1590/S167606032007000300020

Levan A, Fredga K, Sandberg AA. Nomenclature for centromeric position on chromosomes. Hereditas. 1964; 52(2):201-20. https://doi.org/10.1111/j.1601-5223.1964.tb01953.x

Margarido VP, Moreira-Filho O. Karyotypic differentiation through chromosome fusion and number reduction in Imparfinis hollandi (Ostariophysi, Heptapteridae). Genet Mol Biol. 2008; 31(1):235-38. http://dx.doi.org/10.1590/S141547572008000200012

Martins C, Galetti Jr PM. Chromosome localization of 5S rDNA genes in Leporinus fish (Anostomidae, Characiformes). Chromosome Res. 1999; 7(5):363-67. https://doi. org/10.1023/A:1009216030316

Mendes VP, Portela-Castro AL, Julio-Junior HF. First record of supernumerary (B) chromosomes in electric fish (Gymnotiformes) and the karyotype structure of three species of the same order from the upper Paraná River basin. Comp Cytogenet. 2012; 6 (1):1-16. https://doi.org/10.3897/ CompCytogen.v6i1.1752
Nijssen H, Isbrücker IJH, Géry J. On the species of Gymnorhamphichthys Ellis, 1912, translucent sand-dwelling gymnotid fishes from South America (Pisces, Cypriniformes, Gymnotoidei). Stud Neotrop Fauna E. 1976; 11(1-2):37-63. https://doi.org/10.1080/01650527609360496

Ota RR, Deprá GC, Graça WJ, Pavanelli CS. Peixes da planície de inundação do alto rio Paraná e áreas adjacentes: revised, annotated and updated. Neotrop Ichthyol. 2018; 16(2): e170094. https://doi.org/10.1590/1982-0224-20170094

Pinkel D, Straume T, Gray JW. Cytogenetic analysis using quantitative, high-sensitivity, fluorescence hybridization. Proc Natl Acad Sci. 1986; 83(9):2934-38.

Pisano E, Ozouf-Costaz C, Foresti F, Kapoor BG. Fish Cytogenetics. Enfield N. H., Science Publishers Inc (USA); 2007.

Silva EB, Margarido VP. An $\mathrm{X}_{1} \mathrm{X}_{1} \mathrm{X}_{2} \mathrm{X}_{2} / \mathrm{X}_{1} \mathrm{X}_{2} \mathrm{Y}$ multiple sex chromosome system in a new species of the genus Gymnotus (Pisces, Gymnotiformes). Environ Biol Fish. 2005; 73(3):29397. https://doi.org/10.1007/s10641-005-2144-5

da Silva M, Matoso DM, Artoni RF, Feldberg E. New approach data in electric fish (Teleostei: Gymnotus): Sex chromosome evolution and repetitive DNA. Zebrafish. 2014; 11(6):528-35. https://doi.org/10.1089/zeb.2013.0966

Silva PC, Nagamachi CY, Silva DS, Milhomem SSR, Cardoso AL, Oliveira JA, Pieczark JC. Karyotypic similarities between two species of Rhamphichthys (Rhamphichthyidae, Gymnotiformes) from the Amazon basin. Comp Cytogenet. 2013; 7(4):279-91. https://doi.org/10.3897/CompCytogen. v7i4.4366

Sumner AT. A simple technique for demonstrating centromeric heterochromatin. Exp Cell Res. 1972; 75(1):304-06. https:// doi.org/10.1016/0014-4827(72)90558-7

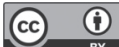

Submitted July 1, 2019 Accepted September 9, 2019 by Claudio Oliveira 